\title{
The Heather Vole, Genus Phenacomys, in Alaska
}

\author{
S. O. MacDonald ${ }^{1,3}$, Amy M. RunCK${ }^{2}$, and Joseph A. Cook ${ }^{3, *}$
}

${ }^{1}$ P.O. Box 58, Gila, New Mexico 88038-0058 USA

${ }^{2}$ Biological Sciences Department, Idaho State University, Pocatello, Idaho 83209-8007 USA

${ }^{3}$ Museum of Southwestern Biology, University of New Mexico, Albuquerque, New Mexico 87131 USA; Corresponding author, e-mail cookjose@unm.edu

MacDonald, S. O., Amy M. Runck, and Joseph A. Cook. 2004, The heather vole genus Phenacomys, in Alaska. Canadian Field-Naturalist 118(3): 438-440.

Four specimens of heather vole (genus Phenacomys) collected in the coastal mountains of Southeast Alaska document the first Recent records of this vole in Alaska. Alternative hypotheses on the relationship of these newly-discovered populations to extant and historical populations are outlined, and additional studies proposed.

Key Words: Heather vole, Phenacomys sp., Southeast Alaska.

Since publication of a synopsis of the land mammal fauna of Southeast Alaska (MacDonald and Cook 1996), new field and laboratory studies of the mammals of this region have resulted in new perspectives on the zoogeography of the North Pacific Coast (Conroy et al. 1999; Cook and MacDonald 2001; Cook et al. 2001). In our 1996 publication, we speculated that several mammal species found on the eastern side of the coastal mountains in Canada may occur along the Alaska coast. One species, the heather vole (Phenacomys intermedius), had previously been recorded within $2 \mathrm{~km}$ of the southern Alaska border in the subalpine near Salmon Glacier in British Columbia (approximately $56.17^{\circ} \mathrm{N}, 130.03^{\circ} \mathrm{W}$ ), and Nagorsen and Jones (1981) reported its occurrence in the Chilkat Pass north of Haines and Southeast Alaska. Subsequent trapping efforts in Alaskan mountains near Salmon Glacier and elsewhere along the mainland coast resulted in the capture of four specimens of this vole (Table 1) from two widely separate localities (Figure 1). These specimens, deposited at the University of Alaska Museum (UAM), constitute the first documented records of extant populations of heather vole in Alaska.

On 11 August 1996, we captured a single heather vole (UAM 42371) above timberline in the glaciallyisolated Chilkat Range at the northern end of Southeast Alaska near Excursion Inlet, Glacier Bay National Park $\left(58.41^{\circ} \mathrm{N}, 135.43^{\circ} \mathrm{W}\right.$; elevation approximately $900 \mathrm{~m}$ ). Also recorded in this alpine area were Sorex monticolus and melanistic Marmota caligata.

In 1999, three heather voles were collected from the far southern end of mainland Southeast Alaska, approximately $400 \mathrm{~km}$ south of the 1996 Glacier Bay record. On 23 September 1999, two male (UAM 64239, UAM 64240) and one female (UAM 50000) heather voles were found in subalpine habitat along the Titan Trail in the Reverdy Mountains, approximately 10 $\mathrm{km}$ north of Hyder, Alaska (approximately $55.83^{\circ} \mathrm{N}$, $130.03^{\circ} \mathrm{W}$; elevations between $1128-1220 \mathrm{~m}$ ). Synaptomys borealis was also sampled at this site.
The distribution of the heather vole is poorly known throughout western North America (Figure 1) and geographic variation has been little studied (for overviews see McAllister and Hoffmann 1988; Nagorsen 1990; Musser and Carleton 1993). Some authorities (Anderson 1942; Cowan and Guiguet 1965; Peterson 1966; Hallett 1999) recognized the distinctiveness of western populations ( $P$. intermedius of westcentral British Columbia south to California and New Mexico) and separated them from $P$. ungava in the north and east (southern Yukon Territory and northern British Columbia eastward to Newfoundland) (McAllister and Hoffmann 1988; George 1999); others considered all to comprise a single species (Crowe 1943; Youngman 1975; Honacki et al. 1982; Nagorsen 2004). Hall (1981) speculated that intermedius may be a composite of two or three allopatric species (see McAllister and Hoffmann 1988), but the lack of specimens from too few areas has prevented meaningful progress in resolving the problem. Reluctance of this species to enter traps may be the primary factor limiting sample size and study materials (McAllister and Hoffmann 1988).

The taxonomic affinities of newly-discovered populations of heather vole in Southeast Alaska are not immediately evident. Based on the map provided by Hall (1981: 787, as adjusted by McAllister and Hoffmann 1988 and Nagorsen 2004), Alaska's southernmost heather voles could share close kinship with the $P$. $i$. intermedius group of "western" heather voles occurring in the coastal mountain ranges of adjacent British Columbia. Heather voles from northern Southeast Alaska, on the other hand, might possibly have connection with the "eastern" populations (as P. ungava mackenzii) in northwestern British Columbia and southern Yukon Territory. Both of these scenarios presume relatively recent colonization from inland populations following the (ongoing) retreat of the last major glaciation from the region. A similar scenario has been proposed for American Marten (Martes americana) (Stone et al. 2002) and other mammals (Cook 
TABLE 1. Summary of specimen data from collection notes and records at the University of Alaska Museum (UAM). Alaska Frozen Tissue Number refers to the cryogenic collection administered by UAM. Measurements and abbreviations are as follows: total length-tail length-hind foot-ear from notch (in millimeters) $\equiv$ mass (in grams); $\mathrm{t}=$ testes (length and width in $\mathrm{mm}), \mathrm{plsc}=$ number of placental scars on right and left uterine horn; $\mathrm{F}=$ female, $\mathrm{M}=$ male.

\begin{tabular}{cccc}
\hline \hline UAM Catalog Number & Alaska Frozen Tissue Number & Sex (Reproduction) & Measurements \\
\hline 42371 & 17262 & $\mathrm{M}(\mathrm{t}=2 \mathrm{X} 3)$ & $120-31-19-11 \equiv 19$ \\
50000 & 30176 & $\mathrm{~F}(\mathrm{plsc}:$ R , $0 \mathrm{~L})$ & $156-37-18-14 \equiv 33.9$ \\
64239 & 30178 & $\mathrm{M}(\mathrm{t}=3 \mathrm{X} 2)$ & $129-32-17-13 \equiv 22.8$ \\
64240 & 30179 & $\mathrm{M}(\mathrm{t}=3 \mathrm{X} 2)$ & $115-26-16-10 \equiv 14.6$ \\
\hline \hline
\end{tabular}

et al. 2001). An alternative hypothesis, however, is that one or more of these populations are remnants of a former coastal population whose origin in the region preceded the last glacial advance (MacDonald and Cook 1996; Fleming and Cook 2002).

The discovery of late Pleistocene fossil remains of Phenacomys in limestone cave deposits in the Alexander Archipelago of Southeast Alaska has added historical dimension to these hypotheses. Preliminary analyses of thousands of rodent teeth recovered from On Your Knees Cave at the extreme northwest corner of Prince of Wales Island in Southeast Alaska (Figure 1) (Heaton 1995, 2004*; Heaton and Grady 2003) indicate that Heather Voles had been present in the vicinity of this site during the Middle Wisconsin up to the start of, but not during or following, the last glacial maximum (between about 24000 to 13000 years ago) (Heaton 2004*; Heaton and Grady 2003). Other



FIGURE 1: Localities of specimens of Phenacomys in Southeastern Alaska from Recent and Late Pleistocene sites. Inset range map modified according to McAllister and Hoffman (1988) following subspecific designations suggested by George (1999) and Hallett (1999). 
rodent remains discovered in these same pre-glacial deposits were Brown Lemming, Lemmus trimucronatus, a species thought absent from the region but recently discovered by UAM in the mountains near Haines, and the Hoary Marmot, Marmota caligata, a species now restricted to mainland localities.

How the new records of Phenacomys from Southeast Alaska relate to extant and historical populations has yet to be determined. Analyses of samples using modern molecular and morphological techniques could help clarify these relationships and provide a test of alternate hypotheses on the origin and dynamics of the region's biota. Clearly, more samples from more localities are needed. An expanded effort to excavate fossils throughout the region, along with a continuation of survey efforts to further define the current distribution of Phenacomys and other mammals that share a deep history in the region (e.g., Lemmus, Marmota), as well as provide adequate samples for assessment, are needed. The alpine zone of Southeast Alaska is virtually unexplored and future inventories need to target sites above treeline along the mainland as well as on the more mountainous islands in the Alexander Archipelago.

\section{Acknowledgments}

A number of individuals assisted with field work that led to these new records including C. T. Seaton, Able Duffy, Joni Reese, Mike Brown, Guillermo D'Elia, and John Chythlook. Brandy Jacobsen, Gordon Jarrell, and Dusty McDonald of the University of Alaska Museum provided specimen information. Thanks also to David Nagorsen for reviewing an early draft of this paper. This research was funded by the United States Fish and Wildlife Service, United States Department of Agriculture Forest Service, Alaska Cooperative Fish and Wildlife Research Unit, and the National Science Foundation (DEB0196095 \& DEB9981915).

Documents Cited [marked $*$ in text citations]

Heaton, T. H. 2004. Ice Age paleontology of Southeast Alaska. http://www.usd.edu/esci/alaska/index.html. 3 December 2004.

\section{Literature Cited}

Anderson, R. M. 1942. Canadian voles of the genus Phenacomys with description of two new Canadian subspecies. Canadian Field-Naturalist 56: 56-60.

Conroy, C. J., J. R. Demboski, and J. A. Cook. 1999. Mammalian biogeography of the Alexander Archipelago of Alaska: a north temperate nested fauna. Journal of Biogeography 26: 343-352.

Cook, J. A., and S. O. MacDonald. 2001. Should endemism be a focus of conservation efforts along the North Pacific Coast of North America? Biological Conservation 97: 207-213.

Cook, J. A., A. L. Bidlack, C. J. Conroy, J. R. Demboski, M. A. Fleming, A. M. Runck, K. D. Stone, and S. O. MacDonald. 2001. A phylogeographic perspective on endemism in the Alexander Archipelago of southeast Alaska. Biological Conservation 97: 215-227.
Cowan, I. M., and C. J. Guiguet. 1965. The mammals of British Columbia. British Columbia Provincial Museum, Handbook No. 11, $2^{\text {nd }}$ edition: 1-414.

Crowe, P. E. 1943. Notes on some mammals of the southern Canadian Rocky Mountains. Bulletin of the American Museum of Natural History 80: 391-410.

Fleming, M. A., and J. A. Cook. 2002. Phylogeography of endemic ermine (Mustela erminea) in southeast Alaska. Molecular Ecology 11: 795-808.

George, S. B. 1999. Eastern heather vole, Phenacomys ungava. Pages 618-619 in The Smithsonian book of North American mammals. Edited by D. E. Wilson and S. Ruff. Smithsonian Institution Press, Washington, D.C., in association with the American Society of Mammalogists. 750 pages.

Hall, E. R. 1981. The mammals of North America. WileyInterscience, New York. 1181 pages.

Hallett, J. G. 1999. Western heather vole, Phenacomys intermedius. Pages 617-618 in The Smithsonian book of North American mammals. Edited by D. E. Wilson and S. Ruff. Smithsonian Institution Press, Washington, D.C., in association with the American Society of Mammalogists. 750 pages.

Heaton, T. H. 1995. Middle Wisconsin bear and rodent remains discovered on Prince of Wales Island, Alaska. Current Research in the Pleistocene 12: 92-94.

Heaton, T. H., and F. Grady. 2003. The Late Wisconsin vertebrate history of Prince of Wales Island, Southeast Alaska. Pages 17-53 in Ice Cave Faunas of North America. Edited by B. W. Schubert, J. I. Mead, and R. W. Graham. Indiana University Press. 400 pages.

Honacki, J. H., K. E. Kinman, and J. W. Koeppl. Editors. 1982. Mammal species of the world: a taxonomic and geographic reference. Allen Press, Inc. and The Association of Systematics Collections, Lawrence, Kansas. 694 pages.

MacDonald, S. O., and J. A. Cook. 1996. The land mammal fauna of southeast Alaska. Canadian Field-Naturalist 110: 571-599.

McAllister, J. A., and R. S. Hoffmann. 1988. Phenacomys intermedius. Mammalian Species 305: 1-8.

Musser, G. G., and M. D. Carleton. 1993. Family Muridae. Pages 501-756 in Mammal species of the world: a taxonomic and geographic reference. Edited by D. E. Wilson and D. M. Reeder. Second Edition. Smithsonian Institution Press, Washington. 1206 pages.

Nagorsen, D. W. 1990. The mammals of British Columbia: a taxonomic catalogue. Memoir Number 4, Royal British Columbia Museum. 140 pages.

Nagorsen, D. W. 2004. The rodents and lagomorphs of British Columbia. Royal British Columbia Museum Handbook, Volume 4. University of British Columbia Press, Vancouver. 352 pages.

Nagorsen, D. W., and D. M. Jones. 1981. First records of the Tundra Shrew (Sorex tundrensis) in British Columbia. Canadian Field-Naturalist 95: 93-94.

Peterson, R. L. 1966. The mammals of eastern Canada. Oxford University Press, Toronto. 465 pages.

Stone, K., R. Flynn, and J. Cook. 2002. Post-glacial colonization of northwestern North America by the forest associated American marten (Martes americana). Molecular Ecology 11: 2049-2064.

Youngman, P. M. 1975. Mammals of the Yukon Territory. National Museum of Natural History, Publications in Zoology 10: 1-192.

Received 26 November 2002

Accepted 30 December 2004 